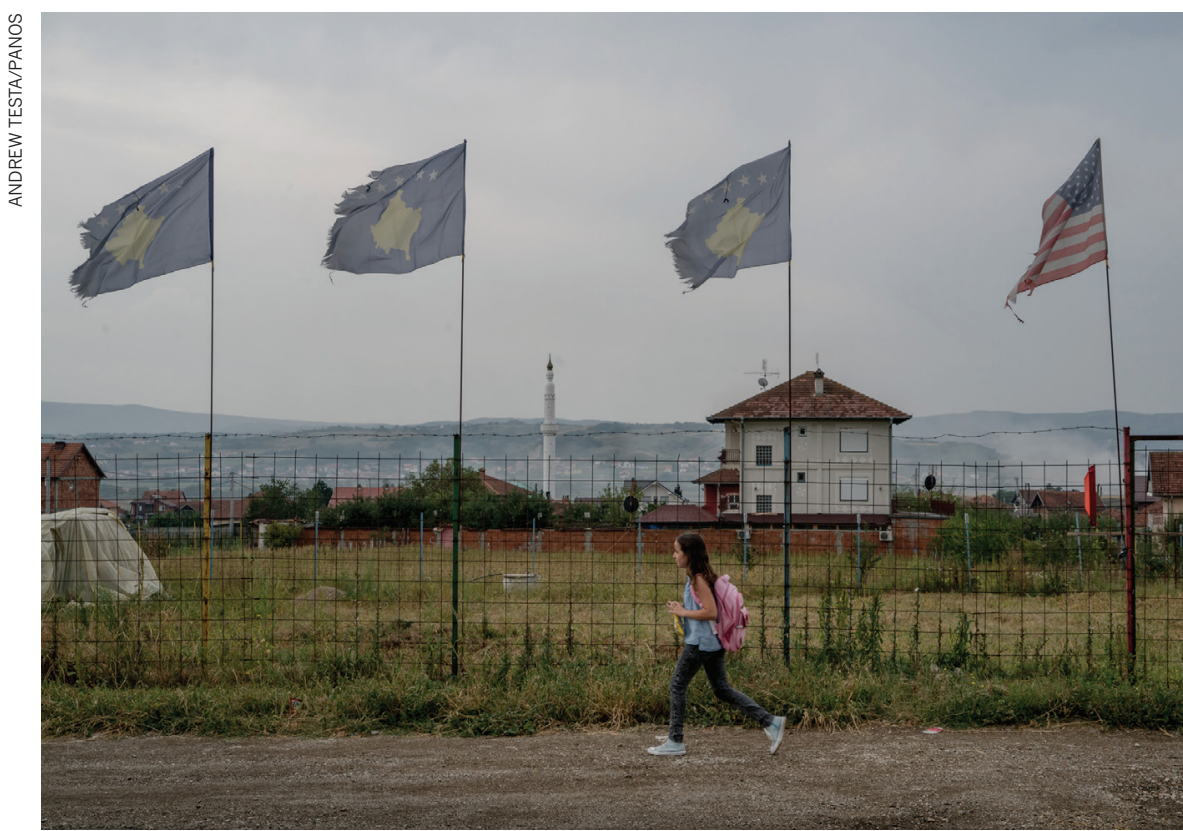

A NATO-led force still protects the fragile peace in Kosovo.

(see 'Rethinking borders').

Mitrovica, which lies near the Serbian border, hosts two institutions that would feel the effects of a land swap keenly. One is the University of Priština, which, during the war in 1998-99, fled from Priština to Mitrovica; it is the only university in Kosovo that still teaches in Serbian. The second is the English-language International Business College-Mitrovica (IBCM) - the only higher-education institution teaching Serbs and Albanians under the same roof.

\section{A DIVIDED CITY}

The University of Priština has some 10,000 students across 10 faculties who come here from the wider region and neighbouring countries, boosting the local population to around 15,000 - and in turn helping the local economy, says Dušan Radaković, who runs a non-governmental organization in Mitrovica called the Advocacy Center for Democratic Culture. "The university has turned Mitrovica into a college town: the whole population lives from it," he says.

It has also been a source of confidence for Kosovo's Serbs. The university is located in a Serbian enclave that is still not fully integrated into Kosovo and is funded by the Serbian government: academics get special bonuses as an incentive to work there. As a result, the university teaches in Serbian, and that has encouraged Serb academics to stay.

It has even set the scene for some of them to start research collaborations with Albanian colleagues. Such collaboration was unheard of for decades, say several local academics. Jelena Đokić, a technical scientist at the university who works on environmental protection, says that if things remain peaceful, more joint research projects could start in the next couple of years, especially if there is a push and support from the international community. She already has a joint project with an Albanian colleague to study local pollution from old smelters in the area.

Another example of cross-ethnic collaboration is the IBCM, which was split into Serb and Albanian campuses when it opened in 2010. considered both pioneering and controversial. "It was an achievement just having the students in the same school," says Yannick du Pont, based in Istanbul, who directs a Dutch educational non-governmental organization, Spark, that managed the IBCM at the time.

In 2016, the school took the integration further: staff and students from both ethnicities now work together at both campuses. "The last time I had seen Serbs and Albanians in the same classroom in Kosovo before this was when I was in kindergarten," says Đokić, aged 54. Nenad Todorović, a publicrelations officer at the IBCM, gives the credit for the success of the integration to the institution's ban on any talk of politics. "And English as the teaching language has helped." It is unclear which country Mitrovica would end up in if the land swap goes ahead, but either way, the motivation - even the need - for multi-ethnic education pioneered by the IBCM will disappear.

The University of Priština, too, could be at risk. If Mitrovica is officially returned to Serbia, it could lose its unique status as a Serbian bastion within Kosovo. But if it remains in Kosovo, yet outside Serbian control, the university will have to apply for Kosovo's accreditation just to keep running - and Serbian academics are likely to leave. Both options leave academics uncertain about the future. "Nobody knows what will happen," says Đokić. "Nobody asks us, and we have no power over such decisions." Accepting students from both ethnicities was

\section{UK \& IRELAND}

\section{Brexit threatens Irish science}

\author{
Peace and EU have fostered \\ island's research ecosystem.
}

\section{BY DECLAN BUTLER}

S cientists in Northern Ireland and the Republic of Ireland are worried that Brexit will upset the island's research ecosystem, which has benefited from peace and economic growth over the past 20 years.

The 1998 Good Friday Agreement — which brought peace to Northern Ireland after three decades of conflict - has fostered a de facto all-island education and research community, says Jane Ohlmeyer, a historian at Trinity College Dublin and co-chair of the Royal Irish Academy's cross-border Brexit taskforce, which is assessing the impacts of Brexit on research and higher education. The UK split from the European Union now threatens that community, say researchers.

Goods and services currently flow freely between Northern Ireland - part of the United Kingdom - and Ireland, in part because both are members of the EU. But the United Kingdom's looming departure could require customs and other border checks. The issue has been a major sticking point in UK-EU negotiations because a 'hard' border is unpalatable to many politicians, citizens and scientists, and would violate the terms and spirit of the peace agreements. (As Nature went to press, UK politicians were scheduled to vote on 29 January on a Brexit withdrawal deal that contains provisions to ensure the border remains open permanently.)

$\mathrm{UK}$ and Irish membership of the EU has improved cross-border collaboration because it allows for seamless exchange of personnel, equipment, reagents and data, says Catherine Godson, a molecular biologist at University College Dublin. Border restrictions or differences in regulations would stymie this, she says. In turn, cross-border working has helped with community integration and the peace process, says Ohlmeyer.

Northern Ireland is especially vulnerable to Brexit because it is already geographically isolated from the rest of the United Kingdom, and politically from the south, says Gerry McKenna, a former president of the north's Ulster University who co-chairs the Brexit taskforce with Ohlmeyer. Northern Irish scientists also frequently partner with colleagues in the Republic in bids for funding from the EU's Horizon 2020 research programme - and Brexit risks harming these ventures. Labs in Northern Ireland are already struggling to recruit non-UK EU nationals, says Godson. 